\title{
PENGARUH LAYANAN PENGUASAAN KONTEN TERHADAP MOTIVASI DAN PRESTASI BELAJAR BIDANG STUDI BAHASA INDONESIA SISWA KELAS XI IPS SMA NEGERI 1 GLAGAH BANYUWANGI
}

\author{
Oleh : \\ Endang Minarni, ${ }^{1}$ Makmuri, ${ }^{2}$ Asri Widiatsih, ${ }^{3}$ \\ SMA Negeri 1 Glagah Banyuwangi, ${ }^{1}$ IKIP PGRI Jember ${ }^{2,3}$ \\ Endangmr249@yahoo.co.id
}

\begin{abstract}
:
Education means being aware of what will be done to others between adults for children, prenatal age to adulthood to look for the expected goals. Motivation is a spirit from within you both physically and psychologically that is very supportive and very supportive in supporting it. All will have high spirits and strong will do all activities or activities that really to understand the potential that is owned, so that it will be very content and durable in a sustainable manner. The purpose of improving functions in counseling is in accordance with the interests of the child or adult for the process of learning or training in daily life. Role playing is usually recognized by role playing and character so that it expresses corrections to develop abilities in conversation. Role playing (role played) is a strategy used in playing a person's character in drama, his attitude and character can be used to behave as a character being played, so students who are less able to support can carry out activities that are in accordance with the language of motion without interpreting oral language, but through this potential can communicate well, actively, and creatively in accordance with their talents and abilities. The reasons for using content mastery services are: (1) increasing the potential needed by students in the form of communication through, expression, movement, and behavior, because language can also be accessed through certain signals delivered; (2) increasing freedom through the movements needed to play a character, so as to encourage visitors; (3) improve skills in compiling texts that want to succeed in the stories to be taken
\end{abstract}

Keywords: Content Mastery Services, Motivation and Achievement, Indonesian Language

\begin{abstract}
Abstrak:
Pendidikan adalah perilaku sadar yang berasal dalam diri seseorang yang akan dilakukan pada orang lain antara orang dewasa kepada anak, usia prenatal hingga dewasa untuk mengarahkan cita-cita yang diharapkan. Motivasi merupakan semangat dari dalam diri baik secara fisik dan psikis sangat mendukung dan berpengaruh sekali dalam mencapai kemampuan tersebut. Seseorang akan mempunyai semangat tinggi dan kuat maka akan melakukan semua kegiatan atau aktifitas yang sungguh-sungguh untuk menguasai potensi yang dimiliki, sehingga akan sangat konten dan awet secara berkesinambungan. Tujuan dari penguasaan secara khusus adalah meningkatkan fungsi-fungsi dalam konseling sesuai dengan kepentingan anak maupun orang dewasa untuk menjalani proses pembelajaran maupun latihannya dalam kehidupan sehari-hari. Role playing yang biasa dikenali dengan bermain peran dan watak sehingga memuculkan ekspresi-ekspresi untuk mengembangkan kemampuan dalam berkomunikasi. Role playing (bermain peran) adalah suatu strategi yang digunakan dalam permainan watak seseorang dalam bermain drama, sikap dan karakternya bisa digunakan untuk berperilaku sebagai tokoh yang dimainkan, sehingga siswa yang kurang mampu berkomunikasi bisa melakukan kegiatan tersebut dengan bahasa gerak tanpa harus memaknai bahasa lisan, namun melalui potensi tersebut bisa berkomunikasi dengan baik, aktif, dan kreatif sesuai bakat dan kemampuan yang dimiliki. Alasan digunakan layanan penguasaan konten yaitu: (1) meningkatkan potensi yang dimiliki siswa dalam bentuk komunikasi melalui, mimik, gerak, dan tingkah laku, karena bahasa juga bisa dipahami melalui isyarat-isyarat tertentu yang bermakna; (2) meningkatkan keberanian melalui gerakan yang dimiliki untuk memainkan tokoh, sehingga bermakna bagi penonton; (3) meningkatkan keterampilan dalam menyusun naskah yang ingin ditampilkan dalam cerita yang akan ditampilkan
\end{abstract}

Kata kunci: Layanan Penguasaan Konten, Motivasi dan Prestasi, Bahasa Indonesia 


\section{PENDAHULUAN}

Pendidikan adalah perilaku sadar yang berasal dari dalam diri seseorang yang akan dilakukan pada orang lain antara orang dewasa kepada anak pada masa prenatal hingga dewasa yang bersifat mutlak baik dalam kehidupan seseorang, keluarga maupun bangsa dan Negara. Secara jelas tujuan Pendidikan Nasional bersumber dari Sistem Nilai Pancasila yang dirumuskan bahwa Pendidikan Nasional berfungsi mengembangkan kemampuan dan membentuk watak serta peradaban bangsa, bertujuan untuk berkembangnya potensi peserta didik, agar menjadi manusia yang beriman dan bertaqwa kepada Tuhan Yang Maha Esa, berakhlak mulia, sehat, berilmu, cakap, kreatif, mandiri, dan menjadi warga Negara yang demokratis serta bertanggung jawab.

Nyoman S. Degeng (2013:36) Pembelajaran sebagai upaya membelajarkan siswa, dan proses belajar sebagai pengaitan pengetahuan baru pada struktur kognitif yang sudah dimiliki si belajar. Belajar adalah usaha seseorang yang dilakukan secara sengaja dan berusaha untuk bisa melalui proses penting guna mencapai suatu perubahan perilaku. Perilaku individu akan berbeda apabila proses belajarnya dilakukan dengan sungguh-sungguh dan akan lebih cepat dalam memahami apa yang akan dilakukan baik sengaja ataupun tidak disengaja, sehingga melaui belajarlah anak akan lebih cepat mengerti, memahami, menganalisa, dan mendefinisikan sesuatu yang dipelajari. Oleh karena itu belajar sangat diharapkan mulai dari masa prenatal hingga dewasa. Menurut Skinner, seperti yang dikutip Barlosw (1985) belajar adalah suatu proses adaptasi (penyesuaian tingkah laku) yang berlangsung secara progresif.

Motivasi adalah semangat yang berasal dari dalam dirinya dan hati nurani, sehingga segala sesuatu impian yang didasari secara lahir batin akan sangat kuat dan sulit untuk dialihkan, sehingga segala impian yang didasari dengan kemauan dan tekanan yang kuat pasti akan menghasilkan cita-citanya. Motivasi juga dapat diartikan dorongan dari dalam diri sendiri karena adanya suatu rangsangan dari luar yang membangkitkan kemauan untuk bertindak dan menyelesaikan masalah yang dihadapi saat itu, tanpa harus disuruh, atau diperintah oleh orang lain.

Layanan penguasaan konten merupakan layanan yang diberikan untuk mengembangkan potensi diri secara utuh, sehingga potensi akademik dan non akademik bisa terarah sesuai keinginan peserta didik. Layanan konten ini sangat bermanfaat dan sangat dibutuhkan oleh siswa, guru, maupun orang tua, karena layanan tersebut akan mempermudah menemukan sarana pengembangannya sesuai dengan potensi yang dimiliki peserta didik tersebut.

Bermain peran (Role Playing) mempunyai kelebihan, yaitu: (1) siswa lebih berani dalam bermain watak untuk memahami peran dan menguasai isi dari peran yang dimainkan, (2) siswa lebih berkreatif dan mudah menghafal melalui gerakan walaupun ada kesulitan untuk berkomunikasi dengan suara sehingga digantikan oleh gerakan non verbal, (3) siswa dapat berekspresi dalam memerankan mini drama, (4) muculnya kerjasama tim dan kekompkana, (5) memupuk rasa tanggung jawab setiap peranan yang diperankan.

Berdasarkan pendapat dan pemikiran penulis maka masalah berkembang sebagai berikut:

1. Adakah pengaruh layanan penguasaan konten menggunakan teknik Role Playing pada semangat belajar anak dalam mata pelajaran Bahasa Indonesia kelas XI SMA Negeri 1 Glagah Banyuwangi Semester Genap Tahun Pelajaran 2017-2018.

2. Adakah pengaruh layanan penguasaan konten menggunakan teknik Role Playing pada prestasi belajar mata pelajaran Bahasa Indonesia kelas XI Semester Genap, siswa SMA Negeri 1 Glagah Banyuwangi Tahun Pelajaran 2017-2018.

3. Adakah pengaruh layanan penguasaan konten menggunakan teknik Role Playing pada motivasi belajar siswa dan prestasi belajar anak mata pelajaran Bahasa Indonesia kelas XI SMA Negeri 1 Glagah Banyuwangi Semester Genap Tahun Pelajaran 2017-2018.

\section{METODE}

Penelitian ini merupakan quasi experimental (eksperimen semu), dengan model desain Pretest-Posttest Group Design. Model group design dipilih dengan pertimbangan bahwa dalam eksperimen semu, tidak memungkinkan untuk merandom subjek dalam kelompok populasi secara utuh. Selanjutnya pretest dan posttest berarti memberikan tes kepada subjek sebelum dan setelah perlakuan diberikan pada masing-masing kelompok. 
Kelompok besar dalam penelitian ini adalah seluruh audien anak kelas XI IPS di SMAN 1 Glagah, sebanyak 100 siswa aktif dan produktif dalam kegiatan belajar mengajar.

\section{Tabel 1 Populasi Kelas XI IPS}

\begin{tabular}{|c|c|c|}
\hline No. & Kelas & Jumlah Siswa \\
\hline 1. & XI IPS A & 32 \\
\hline 2. & XI IPS B & 35 \\
\hline 3. & XI IPS C & 33 \\
\hline \multicolumn{2}{|c|}{ Jumlah } & 100 \\
\hline
\end{tabular}

Cara pengambilan data ini terdapat dua jenis yaitu, pengambilan data utama dan pengambilan data pendukung. Data-data yang akan dikumpulkan dengan menggunakan instrumen dan cara pengambilan data yang digunakan pada penelitan ini, lebih lanjut dapat diketahui berdasarkan:

Tabel 2 Teknik Pengumpulan Data

\begin{tabular}{|c|c|c|c|}
\hline Variabel & $\begin{array}{c}\text { Metode } \\
\text { Pengumpu } \\
\text { lan Data } \\
\end{array}$ & $\begin{array}{c}\text { Teknik } \\
\text { Pengumpulan } \\
\text { Data } \\
\end{array}$ & $\begin{array}{l}\text { Instrumen } \\
\text { Penelitian }\end{array}$ \\
\hline \multirow[b]{2}{*}{$\begin{array}{l}\text { Motiva } \\
\text { si } \\
\text { belajar }\end{array}$} & Utama & Kuesioner & $\begin{array}{c}\text { Kuesioner } \\
\text { Motivasi } \\
\text { belajar }\end{array}$ \\
\hline & Pelengkap & $\begin{array}{c}\text { Observasi dan } \\
\text { Wawancara }\end{array}$ & 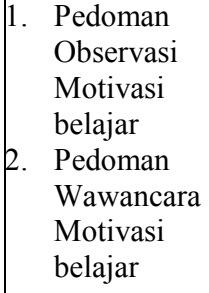 \\
\hline \multirow[b]{2}{*}{$\begin{array}{c}\text { Prestasi } \\
\text { belajar }\end{array}$} & Utama & Tes & $\begin{array}{l}\text { Tes Prestasi } \\
\text { belajar }\end{array}$ \\
\hline & Pelengkap & $\begin{array}{c}\text { Observasi dan } \\
\text { Wawancara }\end{array}$ & \begin{tabular}{|ll} 
1. & Pedoman \\
Observasi \\
Prestasi \\
belajar \\
2. & Pedoman \\
Wawancara \\
Prestasi \\
belajar
\end{tabular} \\
\hline
\end{tabular}

\section{HASIL DAN PEMBAHASAN}

Kondisi motivasi belajar dan semangat belajar siswa kelas XI IPS SMA Negeri 1 Glagah dapat dilihat dari hasil pemberian skala motivasi belajar dan nilai hasil kemampuan belajar. Kelompok dalam penelitian adalah anak-anak kelas XI IPS SMA Negeri 1 Glagah yang berjumlah seratus orang. Berdasarkan hasil sebaran kuesioner dan nilai Bahasa Indonesia seratus siswa tersebut, maka kondisi semangat belajar dan kemampuan belajar siswa kelas XI IPS di SMAN 1 Glagah dijelaskan melalui tabel 3 dan 4. 
Tabel 3

Hasil Penyebaran Skala Semangat Belajar Anak Kelas XI IPS SMA Negeri 1 Glagah (Pretest)

\begin{tabular}{|c|c|c|c|c|c|c|c|}
\hline \multirow{5}{*}{ Kelas } & \multicolumn{6}{|c|}{ Motivasi Belajar } & \multirow{5}{*}{ Jumlah } \\
\hline & \multirow{3}{*}{\multicolumn{2}{|c|}{$\frac{\text { Rendah }}{(40-79)}$}} & \multicolumn{4}{|c|}{ (Rentang Skor) } & \\
\hline & & & \multirow{2}{*}{\multicolumn{2}{|c|}{$\begin{array}{l}\text { Sedang } \\
(80-119)\end{array}$}} & & \multirow{2}{*}{$\frac{\text { inggi }}{0-160)}$} & \\
\hline & & & & & & & \\
\hline & $\mathrm{F}$ & $\%$ & $\mathrm{~F}$ & $\%$ & $\mathrm{~F}$ & $\%$ & \\
\hline XI IPS A & 9 & $28.12 \%$ & 18 & $56.25 \%$ & 5 & $15.63 \%$ & 32 \\
\hline XI IPS B & 16 & $45.71 \%$ & 16 & $45.71 \%$ & 3 & $8.58 \%$ & 35 \\
\hline XI IPS C & 14 & $42.42 \%$ & 17 & $51.51 \%$ & 2 & $6.07 \%$ & 33 \\
\hline Jumlah & \multicolumn{2}{|c|}{39} & \multicolumn{2}{|c|}{51} & \multicolumn{2}{|c|}{10} & \multirow{2}{*}{100} \\
\hline$\%$ & \multicolumn{2}{|c|}{$39 \%$} & \multicolumn{2}{|c|}{$51 \%$} & \multicolumn{2}{|c|}{$10 \%$} & \\
\hline
\end{tabular}

Tabel 4

Hasil Penyebaran Skala Semangat Belajar Anak Kelas XI IPS SMA Negeri 1 Glagah (Posttest)

\begin{tabular}{|c|c|c|c|c|c|c|c|}
\hline \multirow{5}{*}{ Kelas } & \multicolumn{6}{|c|}{ Motivasi Belajar } & \multirow{5}{*}{ Jumlah } \\
\hline & \multicolumn{6}{|c|}{ (Rentang Skor) } & \\
\hline & \multirow{2}{*}{\multicolumn{2}{|c|}{$\frac{\text { Rendah }}{(40-79)}$}} & \multirow{2}{*}{\multicolumn{2}{|c|}{$\frac{\text { Sedang }}{(80-119)}$}} & \multirow{2}{*}{\multicolumn{2}{|c|}{$\frac{\text { Tinggi }}{(120-160)}$}} & \\
\hline & & & & & & & \\
\hline & $\mathrm{F}$ & $\%$ & $\mathrm{~F}$ & $\%$ & $\mathrm{~F}$ & $\%$ & \\
\hline XI IPS A & 8 & $25 \%$ & 19 & $59.37 \%$ & 5 & $15.63 \%$ & 32 \\
\hline XI IPS B & 7 & $20 \%$ & 18 & $51.42 \%$ & 10 & $28.58 \%$ & 35 \\
\hline XI IPS C & 6 & $\begin{array}{l}18.18 \\
\%\end{array}$ & 15 & $45.45 \%$ & 12 & $36.36 \%$ & 33 \\
\hline Jumlah & \multicolumn{2}{|c|}{21} & \multicolumn{2}{|r|}{52} & \multicolumn{2}{|r|}{27} & \multirow{2}{*}{100} \\
\hline$\%$ & \multicolumn{2}{|c|}{$21 \%$} & & $52 \%$ & \multicolumn{2}{|c|}{$27 \%$} & \\
\hline
\end{tabular}

Selanjutnya perbandingan rata-rata hasil pretest dan posttest dan gain score motivasi belajar dan prestasi belajar yang diperoleh siswa setelah mengikuti layanan penguasaan konten dapat dilihat pada Diagram dibawah ini.

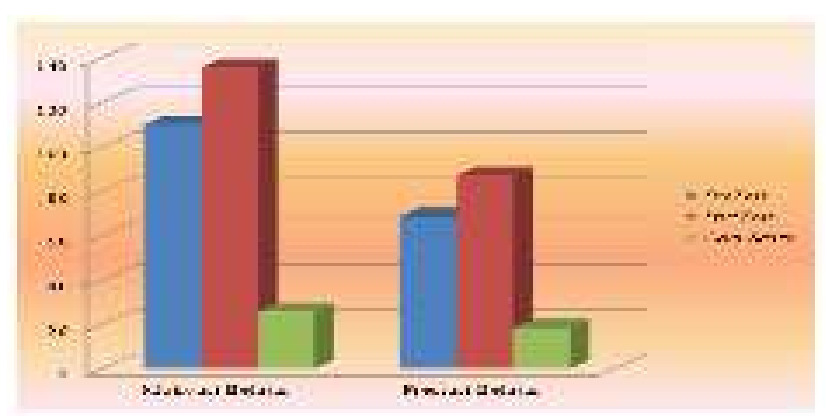




\section{SIMPULAN DAN SARAN}

\section{Simpulan}

Hasil penelitian yang dilakukan peneliti tentang pengaruh layanan penguasaan konten terhadap semangat siswa (motivasi) dan kemampuan belajar (prestasi) bidang studi bahasa indonesia siswa kelas XI IPS yang dilakukan peneliti, maka dapat disimpulkan:

1. Terdapat pengaruh signifikan layanan penguasaan konten dengan teknik Role Playing terhadap motivasi belajar siswa bidang studi Bahasa Indonesia kelas XI SMA Negeri 1 Glagah Banyuwangi Semester Genap Tahun Pelajaran 2017-2018.

2. Terdapat pengaruh signifikan layanan penguasaan konten dengan teknik Role Playing terhadap prestasi belajar bidang studi Bahasa Indonesia kelas XI Semester Genap, siswa SMA Negeri 1 Glagah Banyuwangi Tahun Pelajaran 2017-2018.

3. Terdapat pengaruh layanan penguasaan konten dalam potensi pengembangan diri melalui permainan (role playing) terhadap semangat belajar siswa dan prestasi yang diraih bidang studi Bahasa Indonesia kelas XI SMA Negeri 1 Glagah Banyuwangi Semester Genap Tahun Pelajaran 2017-2018.

\section{PUSTAKA ACUAN}

Abu Ahmadi. 1993. Cara Belajar Mandiri Dan Sukses. Solo: CV Aneka Cipta

Anshar Sunyoto Munandar. 2001. Psikologi Industri dan organisasi. Jakarta: UI Press

Anton Sukarno. 2005. Ciri-Ciri Kemandirian Belajar. Jakarta: Kencana Prenada Media

Arikunto, Suharsimi. 2006. Prosedur Penelitian Suatu Pendekatan Praktik. Jakarta: Rineka Cipta.

Azwar, Syaifudin. 2007. Penyusunan Skala Psikoogis. Yogyakarta: Pustaka Pelajar.

Batara Raya Media. Upaya Meningkatkan Motivasi Belajar Siswa. (Online). (www.batararayamedia.com), diakses 11 Juli 2018

Djamarah, Syaiful Bahri dan Zain, Aswan. 2010. Strategi Belajar Mengajar. Jakarta: PT Rineka Cipta.

Elida Prayitno. 1989. Motivasi Dalam Belajar. Jakarta: Departemen Pendidikan Dan Kebudayaan

Episentrum. 2009. Faktor-faktor yang mempengarushi prestasi. http://episentrum.com/artikel-psikologi/faktorfaktor-yang-mempengaruhi-prestasi/\#more-515. 30 Juli 2018.

Hamalik, Oemar. 2012. Psikologi Belajar dan Mengajar. Bandung: Sinar Baru Algesindo. 
Hariyadi, Sigit. 2011. Upaya Meningkatkan Motivasi Belajar Melalui Layanan Penguasaan Konten Dengan Dukungan Tampilan Kepustakaan Berbasis TIK Di SMA N 2 Ungaran Tahun Ajaran 2010/2011. Skripsi (tidak diterbitkan) Semarang: UNNES. 
